\title{
Silver Nitrate and Different Culture Vessels Influence High Frequency Microrhizome Induction In Vitro and Enhancement Growth of Turmeric Plantlet During Ex Vitro Acclimatization
}

\author{
Dikash Singh THINGBAIJAM, Devala Devi KHUMALLAMBAM, Punyarani \\ KSHETRIMAYUM, Henary Singh CHONGTHAM, Brojendro Singh \\ SHAGOLSEM, Brajakishor S. CHINGAKHAM, Sunitibala Devi HUIDROM* \\ Institute of Bioresources and Sustainable Development, Medicinal Plants and Horticultural Resources Division, Takyelpat \\ Institutional Area, Imphal-795 001, Manipur, India; sunitibala.ibsd@nic.in (*corresponding author)
}

\begin{abstract}
Eleven cultivars of $C$. longa var. Lakadong were collected from Manipur having different topography. Curcumin content in different cultivars has been analyzed by using UV-Visible Spectrophotometer (100 Bio-Carry Spectrophotometer). The curcuminoids content were analyzed and quantified for identification of best quality cultivar. Thoubal Cultivar with highest curcumin content (9.44\%) was subjected for tissue culture technique using different culture vessels and silver nitrate for rapid multiplication and scaling up of microrhizome production. High multiplication rate of $27.40 \pm 0.47$ were obtained in Murashige and Skoog's medium supplemented with 3\% sucrose $+1 \mathrm{mg} \mathrm{L}^{-1} \alpha$-napthalene acetic acid, $4 \mathrm{mg} \mathrm{L}^{-1}$ 6-benzyl-amino-purine and $11 \mu \mathrm{M}$ silver nitrate. Effect of different culture vessels and silver nitrate were studied for microrhizome and multiple shoots formation. Relatively higher rate of shoots along with microrhizome (17.5 \pm 0.32 ) can be seen in Growtek which was grown without any plant growth regulator. Growtek was used for scaling up of microrhizome production in vitro and utmost microrhizome was produced in liquid Murashige and Skoog's medium supplemented with $8 \%$ sucrose, $1 \mathrm{mg} \mathrm{L}^{-1} \alpha$-napthalene acetic acid, $4 \mathrm{mg} \mathrm{L}^{-1}$ 6-benzyl-amino-purine and $11 \mu \mathrm{M}$ silver nitrate (36.25 \pm 0.27$)$. Addition of silver nitrate in the medium resulted in improvement of microrhizome induction in vitro. Higher concentration of silver nitrate $(33,44$, 66, $88 \mu \mathrm{M}$ ) negatively affected the microrhizome and shoot multiplication and shows inhibition of tissue response completely. Analysis of in vitro derived plantlets during acclimatization shows that the exogenous applied of silver nitrate shows superior growth as compared to control. $90-95 \%$ of plantlets with and $75-80 \%$ plantlets without silver nitrate treatment were successfully established under ex vitro acclimatization. The protocol could be utilized for large scale production of true-to-type plantlets and as alternative method to step forward towards an improved commercial propagation system for more efficient and productivity.
\end{abstract}

Keywords: culture vessels, Curcuma longa, Curcumin, rapid microrhizome production, silver nitrate, sucrose

\section{Introduction}

Turmeric (C. longa L.) var. Lakadong is a plant of family Zingiberaceae commonly known as the ginger family and comprises about 70 species (Smart and Simmonds, 1992). Turmeric is found throughout south and Southeast Asia (Pieris, 1982) and used as common condiment for various foods and beverages and has a long history of medicinal uses dating back 2500 years (Shukla and Singh, 2007). Turmeric is known for its aromatic, stimulant, carminative and antihelmintic properties (Satyavati et al., 1976). A yellow-pigmented fraction isolated from the rhizomes of Curcuma contains curcuminoids belonging to the desmethoxycurcumin and bis-desmethoxycurcxumin. It is an important active ingredient responsible for the biological activity of Curcuma. Though the major activity is anti-inflammatory, it has also been reported to possess antioxidant, anti allergic, wound healing, anti-bacterial, anti-fungal and anti-tumor activity (Chattopadhay et al.,
2004). A high consumption of curcumin in the diet is considered safe; it is commonly believed that the cancer chemopreventive and therapeutic properties of curcumin may be accompanied by a lack of toxicity (Lopez-Lazaro, 2008). Structure of curcumin is showing in Fig. 1.

Turmeric is exclusively propagated vegetatively using rhizomes due to poor flowering and seed set. Thus conventional propagation through seed rhizome produces only 10-15 lateral buds in a season of 8-10 months (Bhagyalakshmi and Singh, 1988). Preservation of rhizome seeds is a hard job and required much attention, time and space. Besides they are prone to damage due to different factors such as adverse environment condition, bacterial wilt (Pseudomonas solanacearum), fungal attack (Fusarium oxysporum $f$. sp. zingiberi) and root knot nematode (Melaidoryne incognita) (Dohroo, 1989). Recently, this potent medicinal herb has been propagated by tissue culture techniques as it remains an indispensible tool for rapid multiplication and sustainable growth of slow propagating 
68

species. Propagation through rhizome bud multiplication is an easy and safe method for obtaining uniformity and assures the consistent production of true-to-type plants within a short span of time. Therefore very intensive research and development programmed are needed to overcome the chronic issue of production, yield and quality.

In vitro multiplication of plant such as ginger (Chang and Chiley, 1993; Hosoki and Sagawa, 1977; Inden et al., 1988), Curcuma amada (Borthakur and Bordoloi, 1992), Alpinia galanga (Borthakur et al., 1999) and Curcuma longa (George, 1993; Misra et al., 2004; Nasirujjaman et al,. 2005; Panda et al,. 2007; Prathanturarug et al., 2003; Praveen, 2005; Rahman et al., 2004; Roy and Raychandhari, 2004; Sato et al., 1987; Sunitibala et al., 2001; Vidya et al., 2005) belonging to Zingiberaceae has already been reported. However, there is scant information on methods to induce microrhizome development in $C$. longa using MS (Murashige and Skoog's, 1962) medium modified with Benzyladenine (BA), other plant growth regulators, increased sucrose concentration and modified environmental conditions. Raghu (1997) produce microrhizome on liquid MS medium supplemented with $1.33 \mu \mathrm{M} \mathrm{BA}$, $0.54 \mu \mathrm{M}$ NAA ( $\alpha$-napthalene acetic acid), $1.95 \mu \mathrm{M}$ ancymidol and $10 \%$ sucrose. Sanghamitra and Nayak (2000) produced microrhizome on liquid MS medium with 13.32 $\mu \mathrm{M}$ BA, $6 \%$ sucrose in $4 \mathrm{~h}$ photoperiod. Shirgurkar et al. (2001) found that $4.4 \mu \mathrm{M} \mathrm{BA}$ allowed microrhizome production while Sunitibala et al. (2001) induced microrhizome in MS medium supplemented with $0.54 \mu \mathrm{M}$ NAA, $4.65 \mu \mathrm{M}$ Kinetin and $8 \%$ sucrose.

In recent years, used of silver ions in the form of nitrate, such as silver nitrate $\left(\mathrm{AgNO}_{3}\right)$, play a major role in influencing somatic embryogenesis, shoot formation and efficient root formation which are prerequisites for successful genetic transformation (Bais et al., 1999; $2000 \mathrm{a} ; 2000 \mathrm{~b}$; $2001 \mathrm{a} ; 2001 \mathrm{~b} ; 2001 \mathrm{c})$. $\mathrm{AgNO}_{3}$ has been known to inhibit ethylene actions (Beyer, 1976 a) where, silver ions is capable of specifically blocking the action of exogenously applied ethylene in classical responses such as abscission, senescence and growth retardation (Beyer, 1976 b). These observations led to its application in tissue culture. However, addition of $\mathrm{AgNO}_{3}$ to the culture medium improved the regeneration of both dicots and monocots plant tissue cultures (Bais et al., 2000 a; Beyer, 1976 b; Chi and Pua, 1989; Chithra et al., 2005, Davies, 1987; Duncan et al., 1985; Giridhar et al., 2003; Purnhauser et al., 1987; Songstad et al., 1988). The exact mechanism of $\mathrm{AgNO}_{3}$ actions on plant is still unclear, except, few existing evidences suggest its interference in ethylene perception mechanism (Beyer, 1976 a).

Induction of in vitro microrhizome is an alternative process to produce diseases free plants for commercialization and conservation of germplasm. The onset of rhizome formation is under the control of various environmental, sucrose concentrations and hormonal culture regimes.
However, in the present study, in vitro techniques for rapid clonal propagation of turmeric plant from rhizome buds were undertaken at lower cost. Although effect of plant growth regulators, sucrose concentration and different culture vessels on micropropagation and in vitro formation of microrhizome has been extensively investigated. However, the impact of different culture vessels and used of $\mathrm{AgNO}_{3}$ in scaling up of in vitro microrhizome in turmeric has not been reported so far. The objective of present study were undertaken to enhance the production of in vitro microrhizome by employing tissue culture technique using different hormone combinations, culture vessels, sucrose concentrations and $\mathrm{AgNO}_{3}$ in Curcuma longa L. var. Lakadong.

\section{Materials and methods}

Rhizome of C. longa L. var. Lakadong was collected from different locations of Manipur such as Imphal, Bishnupur, Ukhrul Churachandpur, senapati, Tamenglong and Thoubal in 2010. Standard curcumin and ethyl alcohol were purchased from Sigma Aldrich and Merck respectively. Rhizomes were cleaned thoroughly by repeated washings, air dried, stocked loosely in large utility tray $(360 \times 310 \times 130 \mathrm{~mm}$, Tarson, Kolkata, India $)$ and maintained in the BOD incubator (Narang Scientific Works Pvt. Ltd., New Delhi, India) at ambient temperature $\left(27 \pm 2^{\circ} \mathrm{C}\right)$ under long day condition ( $16 \mathrm{~h}$ light $-8 \mathrm{~h}$ dark). For curcumin estimation, weigh accurately $0.1 \mathrm{~g}$ turmeric extract or $0.005 \mathrm{~g}$ to $0.1 \mathrm{~g}$ curcuminoids in $25 \mathrm{ml}$ ethyl alcohol. Warm it if necessary for the complete dissolution, filter through wattman No. 41, wash the filter paper with little alcohol and transfer it to $100 \mathrm{ml}$ volumetric flask. Make up the volume with ethyl alcohol and pipette $10 \mathrm{ml}$ to another $100 \mathrm{ml}$ volumetric flask, make up the volume with alcohol. Measure the absorbance at $425 \mathrm{~nm}$ in $1 \mathrm{~cm}$ cell against an alcohol blank. Curcumin content was calculated by using the formula (Anonymous, 1984).

Calculations: a standard solution of curcumin 0.0025 $\mathrm{g} / \mathrm{l}$ gives absorbance value of 0.42 at $425 \mathrm{~nm}$.

$$
\begin{aligned}
& \text { Absorptivity }(A)=\frac{0.42}{1 \times 0.0025} \\
& \text { \%of curcuminin extract }=\frac{\mathrm{a} \times 100}{1 \times \mathrm{Ax} \mathrm{W}}
\end{aligned}
$$

$\mathrm{a}=$ absorbance at $425 \mathrm{~nm}$

$\mathrm{I}=$ cell length in $\mathrm{cm}$

A=absorptivity

$\mathrm{W}=\mathrm{Wt}$ of sample of gram

Colour value $=$ Absorbance at $425 \mathrm{~nm} \times 1000$

After selection of best turmeric in terms of its curcumin content, sprouting rhizome buds after two weeks of incubation were cut apart from rhizomes keeping the leaf sheath intact. The redundant roots and other residuals 
were removed from the rhizome buds. The explants were washed scrupulously under running tap water for 15-20 minutes to remove the loose contaminants. The excised rhizome buds were then washed and soaked it for 10-15 minutes with labklin detergent (SD Fine-Chem Limited, Mumbai, India). Subsequently, rinsed thoroughly under running tap water to remove the detergent trace. The clean explants were then treated with gentamycin (HiMedia, Mumbai, India) overnight (antibiotic treatment, $8 \mathrm{mgL}^{-1}$ ). They were washed 5-10 times with distilled water to remove the remaining antibiotic trace. Final surface sterilization was taken out in laminar air-flow cabinet with $0.2 \%$ mercuric chloride $\left(\mathrm{HgCl}_{2}\right)$ (HiMedia, Mumbai, India) for 15 minutes. Then the materials were washed 5 times with sterilized double distilled water to removed $\mathrm{HgCl}_{2}$. After surface sterilization, the outer leaf sheaths were excised with a sterilized surgical scalpel. The explants were then deep in $70 \%$ ethanol and the upper damage tissue were excised with care without damaging the inner portions.

Prepared explants were inoculated aseptically on semi solid Murashige and Skoog's basal medium (MS) supplemented with plant growth hormones (Sigma, St. Louis, USA) 0.5-12.0 mg L-1 BAP (6-benzyl-amino-purine), 0.5$4.0 \mathrm{mg} \mathrm{L}^{-1} \mathrm{NAA}$ ( $\alpha$-napthalene acetic acid), $0.5-8.0 \mathrm{mg} \mathrm{L}^{-1}$ $\mathrm{Kn}$ (Kinetin) (HiMedia, Mumbai, India), 0.5-2.0 $\mathrm{mg} \mathrm{L}^{-1}$ $\mathrm{Zn}$ (Zeatin) (HiMedia, Mumbai, India), $30 \mathrm{~g} \mathrm{~L}^{-1}$ sucrose (HiMedia, Mumbai, India), $11 \mu \mathrm{M}$ silver nitrate (Qualigen, Mumbai, India) and $8 \mathrm{~g} \mathrm{~L}^{-1}$ agar (HiMedia, Mumbai, India). $\mathrm{pH}$ of the medium was attuned to 5.8 prior to adding agar and medium was autoclaved (All American, Manitowoc, West Indies) at $15 \mathrm{lbs}$ psi pressure for 20 minutes at $121^{\circ} \mathrm{C}$. For shoot multiplication experiment, $250 \mathrm{ml}$ phytajars (HiMedia, Mumbai, India,) were used. The cultures were then kept in a growth chamber under 16 hours light photoperiod at $25 \pm 2^{\circ} \mathrm{C}$. Microshoots were initiated after 5-6 weeks. The survived explants were transferred to semi solid MS medium supplemented with $2.0 \mathrm{mg} \mathrm{L}^{-1}$ $\mathrm{BAP}$ and $1 \mathrm{mg} \mathrm{L}^{-1} \mathrm{NAA}$ for the in vitro plant regeneration. Multiple shoot production was observed along with the roots.

The regenerated in vitro plantlets were taken out of the culture vessels and transferred on semi solid MS medium containing varying combination of cytokinins and auxin to get optimum medium for $C$. longa var. Lakadong. The effects of different culture vessels viz. Growtek (Tarson, Kolkata, India, $100 \times 1500 \mathrm{~mm}$ ), planton (Tarson, Kolkata, India, $7.5 \times 10 \mathrm{~cm}$ ), phytajar (HiMedia Mumbai, India, $250 \mathrm{ml}$ ), saveer biotech culture bottle (Saveer Biotech, New Delhi, India, $190 \mathrm{ml}$ and $290 \mathrm{ml}$ ), and culture tube (Borosil, Mumbai, India, $32 \times 200 \mathrm{~mm}$ ) on in vitro microrhizome production were tested. Among the different culture vessels, the best was selected for further experiments using different concentration and combination of plant growth regulators, higher sucrose concentrations with the presence of $\mathrm{AgNO}_{3}$ to enhance the number of microrhizome production.

\section{Anatomical studies}

In vitro and ex vitro derived leaf of C. longa var. Lakadong were used for anatomical studies. Fine T.S (Transverse section) were cut with the help of fine razor, stained with safranin and fast green, and mounted on glass slides with distyrene plastisizer xylene (DPX). Photographs were taken with a camera (SZ-PT, Olympus, Japan) attached to the Stereo Zoom microscope (SZ-PT, Olympus, Japan).

\section{Data analysis}

All the cultures were examined periodically and the number of shoot, height of plantlet, number of microrhizome and weight of microrhizome were recorded every after 3 weeks of initial culture. All the experiments were repeated 3 times, and each treatment contained 20 replicates. Data are expressed as means of three independent experiments. All statistical analyses were performed with SPSS 16.0 (SPSS Inc., Chicago, IL, USA). One-way analysis of variance (ANOVA) was used to compare means.

\section{Results and discussion}

\section{Determination of curcumin content}

Curcuminoids constitutes the major coloring matter in turmeric. The three major constituents were identified as desmethoxycurcumin, bis-desmethoxycurcumin and curcumin. A mixture of curcuminoid in the ethanol extract of powdered samples of Curcuma were analyze by UV-Vis spectrophotometer (100 Bio-Carry UV-Visible Spectrophotometer) and detected at a wavelength of $425 \mathrm{~nm}$. Among the collected cultivars, curcumin content variation was recorded from $1.92 \%$ to $9.44 \%$ in Manipur while $3 \%-4 \%$ in other regions of India (Spice Board of India, 2010). The maximum curcumin content was found to be 9.44\% (Hilly area) and (8.42\%) in Thoubal cultivar having 93.970 longitude, 24.564 latitude followed by Senapati $(6.16 \%)$ and Churchandpur (4.62\%) cultivar respectively (Tab. 1). However, the present study suggested that the Lakadong from Thoubal has more curcumin content than that of others which are found in Manipur. Cultivars with highest curcumin content were than subjected for mass clonal production using simple tissue culture technique.

\section{Culture initiation and multiple shoot production}

Surface sterilized rhizome buds were cultured in semi solid MS medium supplemented with different combination and concentration of plant growth hormones and 11 $\mu \mathrm{M} \mathrm{AgNO}_{3}$. Of the $760(20 \times 38)$ rhizome buds inoculated, 97\% survived and developed multiple shoot along with roots within 4-5 weeks of initial culture. Highest average numbers of shoots along with roots were obtained in MS medium supplemented with BAP (4 mg L $\left.\mathrm{L}^{-1} \mathrm{BAP}\right)$, 
70

Tab. 1. Curcumin content in different cultivars of Lakadong variety found in different locations of Manipur

\begin{tabular}{ccccc}
\hline Cultivar & Place & Longitude & Latitude & Curcumin \% \\
\hline & Imphal east & 93.982 & 24.916 & 1.92 \\
& Senapati & 93.911 & 25.204 & 3.28 \\
& Senapati & 93.976 & 25.169 & 6.16 \\
& Bishnupur & 24.6333 & 93.7667 & 4.47 \\
& Ukhrul & 94.52501 & 25.2797 & 4.05 \\
& Churchanpur & 93.57644 & 24.4528 & 4.33 \\
& Churchanpur & 93.80644 & 23.3128 & 4.62 \\
& Thoubal & 93.998 & 24.680 & 8.42 \\
& Thoubal & 93.970 & 9.44 \\
& Tamenglong & 93.49864 & 24.564 & 3.55 \\
\hline
\end{tabular}

Tab. 2. Effects of different hormones and $\mathrm{AgNO}_{3}$ in in vitro multiple shoots formation $(\mathrm{n}=20)$

\begin{tabular}{|c|c|c|c|}
\hline \multicolumn{3}{|c|}{ Plant growth regulators concentration $(\mathrm{mg} / \mathrm{L})$ with $11 \mu \mathrm{M} \mathrm{AgNO}_{3}$} & \multirow{2}{*}{$\begin{array}{l}\text { No. of shoots } \\
(\text { mean } \pm S E)^{a}\end{array}$} \\
\hline NAA & BAP & Kinetin & \\
\hline 0 & 0 & 0 & 0.00 \\
\hline 0.5 & 1 & & $11.40 \pm 0.48 \mathrm{~m}$ \\
\hline 0.5 & 1.5 & & $13.80 \pm 0.31 \mathrm{n}$ \\
\hline 0.5 & 2 & & $15.80 \pm 0.450$ \\
\hline 1 & 1 & & $15.30 \pm 0.360$ \\
\hline 1 & 1.5 & & $17.25 \pm 0.50 \mathrm{~s}$ \\
\hline 1 & 2 & & $22.25 \pm 0.42 p$ \\
\hline 1 & 4 & & $27.40 \pm 0.47 \mathrm{q}$ \\
\hline 1 & 6 & & $22.50 \pm 0.44 p$ \\
\hline 1 & 8 & & $6.8 \pm 0.11 \mathrm{f}$ \\
\hline 1 & 10 & & $5.30 \pm 0.25 e$ \\
\hline 1 & 12 & & $1.95 \pm 0.63 \mathrm{~d}$ \\
\hline 0.5 & & 1 & $8.15 \pm 0.50 \mathrm{j}$ \\
\hline 0.5 & & 2 & $10.65 \pm 0.32 \mathrm{l}$ \\
\hline 0.5 & & 4 & $13.70 \pm 0.33 n$ \\
\hline 0.5 & & 6 & $7.90 \pm 0.19 \mathrm{i}$ \\
\hline 1 & & 1 & $6.05 \pm 0.19 \mathrm{f}$ \\
\hline 1 & & 2 & $9.25 \pm 0.38 \mathrm{k}$ \\
\hline 1 & & 4 & $7.80 \pm 0.28 \mathrm{i}$ \\
\hline 1 & & 6 & $2.70 \pm 0.14 \mathrm{a}$ \\
\hline
\end{tabular}

${ }^{a}$ Means followed by same letters are not significantly different at $p<0.05$, according to Tukey's comparison test

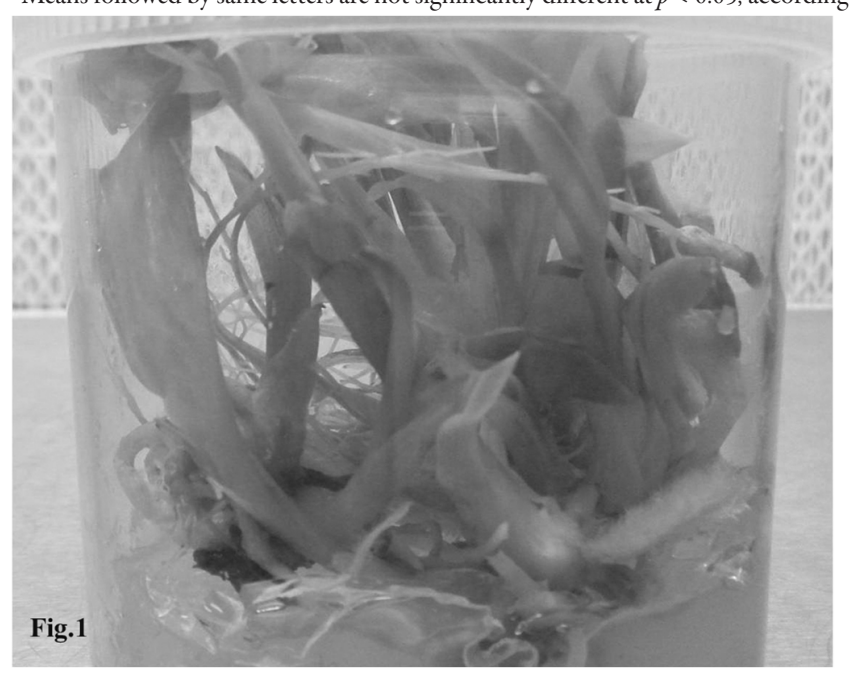

Fig. 1. Multiple shoots formation in $4 \mathrm{mg} \mathrm{L}^{-1} \mathrm{BAP}+1.0 \mathrm{mg} \mathrm{L}^{-1}$ NAA using $250 \mathrm{ml}$ phytajar
$\mathrm{NAA}\left(1 \mathrm{mg} \mathrm{L}^{-1}\right)$ and $11 \mu \mathrm{M} \mathrm{AgNO}_{3}(27.40 \pm 0.47)$ within 4 weeks of culture (Tab. 2, Fig. 1).

The medium having BAP, NAA, Kn or $\mathrm{Zn}$ alone had no effect on shoot multiplication or growth. Interestingly, apart from NAA and BAP combination, NAA in combination with $\mathrm{Kn}$ showed a significant number of multiple shoots ( $8.15 \pm 0.50$ to $13.70 \pm 0.33$ ) as compared with NAA and $\mathrm{Zn}$ combination which shows shoots multiplication of only $1.60 \pm 0.18$ to $2.65 \pm 0.10$. The increase of BAP concentration higher than $8 \mathrm{mg} \mathrm{L}^{-1}$ or Kinetin higher than $4 \mathrm{mg} \mathrm{L}^{-1}$ suppressed the rate of shoot multiplication and shows stunted growth. In the present study, the number of shoots produced was much higher than previous reports by various workers (George, 1993; Misra et al., 2004; Nasirujjaman et al., 2005; Panda et al., 2007; Prathanturarug et al., 2003; Praveen, 2005; Rahman et al., 2004; Roy and Raychandhari, 2004; Sato et al., 1987; 
Sunitibala et al., 2001; Vidya et al., 2005). During the present investigation, highest number of shoot multiplication

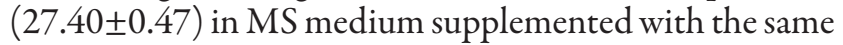
plant growth regulators combination i.e., $4.0 \mathrm{mg} \mathrm{L}^{-1} \mathrm{BAP}$ $+1.0 \mathrm{mg} \mathrm{L}^{-1} \mathrm{NAA}+11 \mu \mathrm{M} \mathrm{AgNO}_{3}$ using $250 \mathrm{ml}$ phytajar (Fig. 1) which is parallel with the finding of Nasirujjaman et al. (2005) reported 6.7 multiple shoots of turmeric on WP medium supplemented with $4.0 \mathrm{mg} \mathrm{L}^{-1} \mathrm{BAP}+1.0 \mathrm{mg}$ $\mathrm{L}^{-1}$ NAA in culture tube. The present findings suggest a high frequency shoot production from a single rhizome bud by manipulating the different plant growth regulators with the presence of $\mathrm{AgNO}_{3}$. Thus, culture medium with a suitable combination and concentration of auxin and cytokinins plays an important role in in vitro shoots multiplication. Misra et al. (2004); Praveen (2005); Vidya et al. (2005) had reported that, higher cytokinin concentration with lower auxin concentration is suitable for shoots multiplication and rooting in C. longa, which is analogous with the present finding. The effect of BAP alone or combination with NAA was also documented by Debergh and Zimmerman (1991) and suggested that herbaceous plants are highly responsive and most cultured herbaceous species produce robust, well-formed shoots suitable for further shoot proliferation to BAP treatments. The plantlets developed in the present investigation were then used for the further experiments.

\section{Effects of different culture vessels on microrbizome} production

The objective of the present study was to achieve highfrequency microrhizome formation by manipulating the culture vessel type. MS liquid medium supplemented with $8 \%$ sucrose was prepared in different culture vessels. The results on the effect of different culture vessels in C. longa var. Lakadong are presented in Tab. 3 (Fig. 2).

Different culture vessels shows different multiplication rate after 35-45 days of incubation. In general, higher sucrose concentration had remarkable effect on the number and size of microrhizome and the ability of $8 \%$ sucrose in induction of in vitro microrhizome was reported by different workers (Garner and Blake, 1989; Shirgurkar et al.,

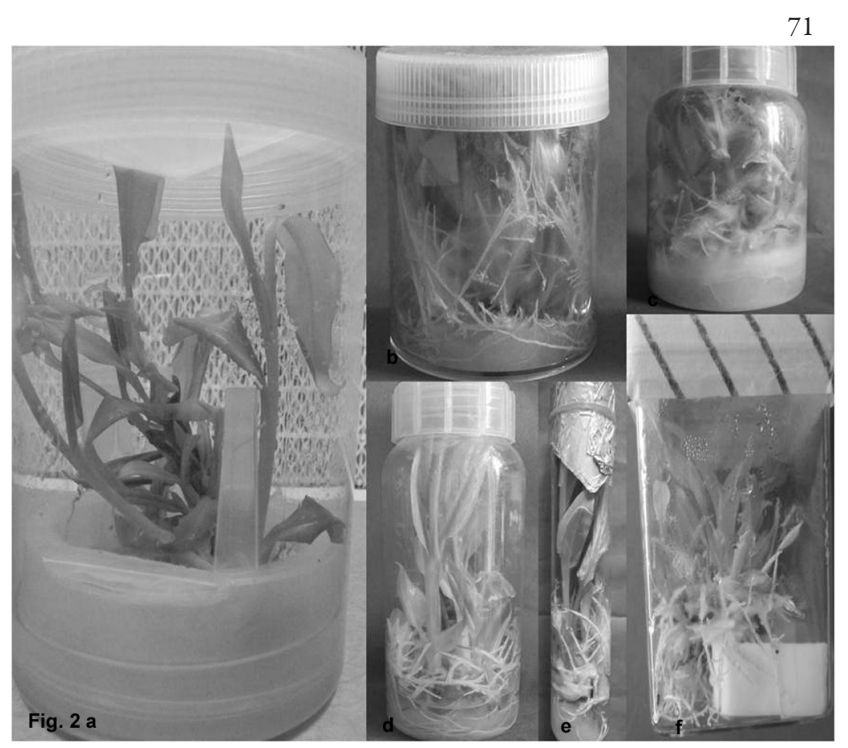

Fig. 2. Effect of different culture vessels on microrhizomes production in (a) Growtek, (b) Phytajar, (c) Saveer culture bottle $190 \mathrm{ml}$, (d) Saveer culture bottle $290 \mathrm{ml}$, (e) Culture tube and (f) Planton

2001; Sunitibala et al., 2001; Vreugdenhil et al., 1998). Thus, highest multiplication rate $(17.50 \pm 0.34)$ with average height of $(13.02 \pm 0.27)$ was seen in Growtek (Fig. 2 a) and minimum multiplication $(3.20 \pm 0.15)$ with average height of (11.30 \pm 0.32$)$ in culture tube (Fig. 2 e). Inspite of producing minimum average number of microrhizome, culture tubes show much larger microrhizome size $(1.64 \pm 0.16)$ as compared to other vessels (growtek$1.01 \pm 0.23$, Fig. 2 a; saveer $290 \mathrm{ml}-0.29 \pm 0.06$, Fig. $2 \mathrm{~d}$; saveer $190 \mathrm{ml}-0.81 \pm 0.23$, Fig. 2 c; phytajar- $0.26 \pm 0.05$, Fig. $2 \mathrm{~b}$ and planton- $0.79 \pm 0.22$, Fig. $2 \mathrm{f}$ ).

Shoot length, proliferation rate, and weight of in vitro microrhizome found to have varied according to culture vessel type. Mackay and Kitto (1988) demonstrated the ratio of explants number to volume of medium, which could cause differences in fresh weight and proliferation rates. The present study examines the effects of different culture vessel type on in vitro microshoot prolifiration and microrhizome development for a range of commer-

Tab. 3. Effect of different culture vessels in plant height, number and weight of microrhizome in in vitro $(\mathrm{n}=20)$

\begin{tabular}{cccc}
\hline Vessel type & $\begin{array}{c}\text { Plant height }(\mathrm{cm}) \\
(\text { mean } \pm \text { SE })^{\mathrm{a}}\end{array}$ & $\begin{array}{c}\text { Average no. of microrhizome per vessel } \\
(\text { mean } \pm \text { SE })^{\mathrm{a}}\end{array}$ & $\begin{array}{c}\text { Average weight of microrhizome }(\mathrm{g}) \\
(\mathrm{mean} \pm \mathrm{SE})^{\mathrm{a}}\end{array}$ \\
\hline $\begin{array}{c}\text { Growth-Tek } \\
(100 \times 1500 \mathrm{~mm})\end{array}$ & $13.02 \pm 0.27 \mathrm{wvz}$ & $17.50 \pm 0.34 \mathrm{drt}$ & $1.01 \pm 0.23 \mathrm{z}$ \\
$\begin{array}{c}\text { Saveer biotech } \\
\text { culture bottle }(290 \mathrm{ml})\end{array}$ & $12.65 \pm 0.35 \mathrm{wvz}$ & $12.70 \pm 0.21 \mathrm{abc}$ & $0.29 \pm 0.06 \mathrm{z}$ \\
$\begin{array}{c}\text { Phytajar } \\
(250 \mathrm{ml})\end{array}$ & $9.77 \pm 0.28 \mathrm{pqr}$ & $10.10 \pm 0.23 \mathrm{prt}$ & $0.26 \pm 0.05 \mathrm{z}$ \\
$\begin{array}{c}\text { Saveer biotech } \\
\text { Culture bottle }(190 \mathrm{ml})\end{array}$ & $6.40 \pm 0.23 \mathrm{yrm}$ & $8.80 \pm 0.13 \mathrm{uvw}$ & $0.81 \pm 0.23 \mathrm{z}$ \\
Planton $(7.5 \times 10 \mathrm{~cm})$ & $5.96 \pm 0.25 \mathrm{yrm}$ & $7.0 \pm 0.29 \mathrm{~lm}$ & $0.79 \pm 0.22 \mathrm{z}$ \\
$\begin{array}{c}\text { Culture tube } \\
(32 \times 200 \mathrm{~mm})\end{array}$ & $11.30 \pm 0.32 \mathrm{swm}$ & $3.20 \pm 0.15 \mathrm{pq}$ & $1.64 \pm 0.16 \mathrm{trm}$
\end{tabular}

${ }^{a}$ Means followed by same letters are not significantly different at $p<0.05$, according to Tukey's comparison test 
72

cially micropropagated turmeric plant, using production methods that parallel commercial standards. Number of microrhizome was significantly greater in all the culture replicate grown in larger vessels i.e. Growtek, than in the culture tube or any other vessels. Response of shoot length, microrhizome number and weight of microrhizome as a function of vessel type, varied from one vessel to another (Tab. 3). Number of microrhizome production increased as vessel-type growing area increased. Growtek not only produced highest number of microrhizome but substantially greater shoot height and microrhizome weight (except culture tube) than explants in any other vessels type. The most striking factor affecting in vitro microrhizome production during the experiment was different vessel type employed. In previous reports, the role of different culture vessels on growth parameters and micro environment of plantlets by the interface between inside and outside environments have been demonstrated by Kacar $e t$ al. (2010) and Huang and Chen (2005). Hence, it can be inferred that rapid clonal multiplication and induction of microrhizome depends on culture vessel, apart from high sucrose concentration. Consequently, larger and taller the culture vessel (Growtek) relatively higher rate of microrhizome formation was observed (Fig. 2 a).

\section{Scaling up of microrbizome production}

The most effective culture vessel (Growtek) was used to scale up the production of in vitro microrhizome production. The average number of microrhizome production in liquid MS medium supplemented with different plant growth regulators and sucrose concentration with $11 \mu \mathrm{M}$ $\mathrm{AgNO}_{3}$ are indicated in Tab. 4 .

Higher level of sucrose with $11 \mu \mathrm{M} \mathrm{AgNO}_{3}$ in the medium significantly influenced microrhizome formation in vitro. No microrhizome could be induced in vitro in the

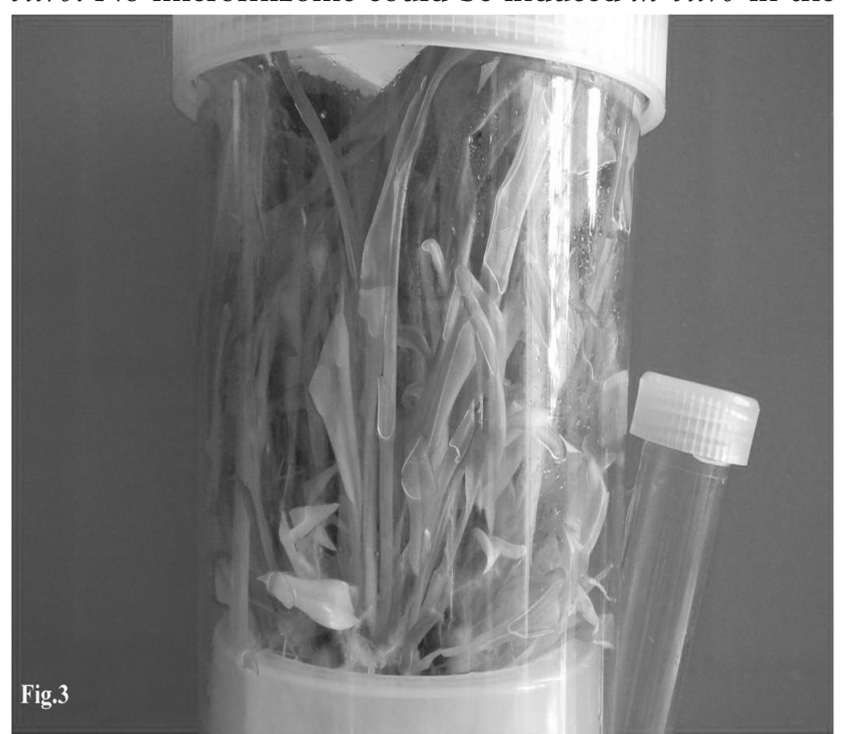

Fig. 3: High frequency microrhizome production using growtek in MS liquid medium supplemented with $8 \%$ sucrose, $1 \mathrm{mg} \mathrm{L}^{-1}$ NAA and $4 \mathrm{mg} \mathrm{L}^{-1} \mathrm{BAP}$ liquid MS medium containing normal concentration of sucrose i.e. 3\%, instead multiplication of shoot was observed. However on liquid MS medium supplemented with $6-10 \%$ sucrose and different combination and concentration of plant growth regulators, swelling up of shoot bases followed by induction of microhizome was observed. The overall response was always better in medium supplemented with $8 \%$ sucrose. Maximum number of microrhizome formation $(36.25 \pm 0.27)$ was seen in liquid MS medium supplemented with $8 \%$ sucrose, $1 \mathrm{mg} \mathrm{L}^{-1} \mathrm{NAA}, 4 \mathrm{mg}$ $\mathrm{L}^{-1} \mathrm{BAP}$ and $11 \mu \mathrm{M} \mathrm{AgNO}_{3}$ (Tab. 4, Fig. 3).

Between the two cytokinins-BAP and Kn tested, $4 \mathrm{mg}$ $\mathrm{L}^{-1} \mathrm{BAP}$ in combination with $80 \mathrm{~g} \mathrm{~L}^{-1}$ sucrose and $1 \mathrm{mg}$ $\mathrm{L}^{-1} \mathrm{NAA}$ was found to be most competent for microrhizome production. This is in conformity with Sharma and Singh (1995), Nayak (2000), Shirgurkar et al. (2001) and Sunitibala et al. (2001). In the present study, the highest number of microrhizome $(36.25 \pm 0.27)$ was in $80 \mathrm{~g} \mathrm{~L}^{-1} \mathrm{su}-$ crose and is much higher than those reported previously by Nayak (2000), Shirgurkar et al. (2001) and Sunitibala et al. (2001). Sharma and Singh (1995) found that Kn was better cytokinin for vegetative bud multiplication than BAP. However, in the present investigation, inclusion of $\mathrm{Kn}$ in combination with NAA does not show mark response on number of microrhizome differentiation but shows larger microrhizome size $\left(0.5 \mathrm{mg} \mathrm{L}^{-1} \mathrm{NAA}+2 \mathrm{mg} \mathrm{L}^{-1} \mathrm{Kn}\right)$ $(1.34 \pm 0.06)$ (Tab. 4) as compared with medium supplemented with BAP and NAA. This is in agreement with the finding of Sunitibala et al. (2001) who reported that $\mathrm{Kn}$ is suitable for in vitro rhizome formation in C. longa L. Further, higher concentrations of sucrose i.e. $10 \%$ had an inhibitory effect on in vitro microrhizome production and show a marked decrease in the percentage of explants response with rhizome formation (Tab. 4). However, 10\% sucrose decreases the number of in vitro microrhizome production in all the culture tested even by increasing the concentration of BAP or Kn.

Plant growth regulators and their interaction with sugar play an important role in the storage organ induction of many plants propagated in vitro. The increase of the sucrose concentration in the medium stimulated the lily and onion bulb formation (Gerrits and De Klerk, 1992; Kastner et al., 2001; Keller, 1993; Takayama and Misawa, 1980), the corm induction of Watsonia vanderspuyiae (Ascough et al, 2008), the microtubers formation of Solanum tuberosum (Gopal et al., 2001), Xanthosoma sagittifolium (Omokolo et al., 2003), Dioscorea cayenensis - D. rotundata complex (Ovono et al., 2009) and the microrhizome production of Zingiber officinale (Sharma et al., 1997). Sugar also act as signaling molecules whose transduction pathways influence developmental and metabolic processes. Some of the effect of sugar on plant growth and development suggest an interaction of sugar signals with hormonal regulation (Rolland et al., 2006; Smeekens, 2000). However, a high level of sucrose in the medium can overcome the cytoki- 
Tab. 4. Effect of different sucrose level, plant growth regulators and with and without silver nitrate in in vitro microrhizome production $(\mathrm{n}=20)$

\begin{tabular}{|c|c|c|c|c|c|c|c|c|c|}
\hline \multicolumn{3}{|c|}{$\begin{array}{l}\text { Plant growth regulators } \\
\text { concentration }(\mathrm{mg} / \mathrm{L})\end{array}$} & \multirow[t]{2}{*}{$\begin{array}{l}\text { Sucrose } \\
\text { conc. (\%) }\end{array}$} & \multirow{2}{*}{$\begin{array}{l}\text { No. of explants with } \\
\text { microrhizome } \\
(\text { mean } \pm \mathrm{SE})^{\mathrm{a}} \\
\text { With } 11 \mu \mathrm{M} \mathrm{AgNO}\end{array}$} & \multirow{2}{*}{$\begin{array}{l}\text { Average weight of } \\
\text { microrhizome }(\mathrm{g}) \\
(\text { mean } \pm \mathrm{SE})^{\mathrm{a}} \\
\text { With } 11 \mu \mathrm{M} \mathrm{AgNO}\end{array}$} & \multirow{2}{*}{$\begin{array}{l}\text { No. of explants with } \\
\text { microrhizome } \\
(\text { mean } \pm \mathrm{SE})^{\mathrm{a}} \\
\text { Without } \mathrm{AgNO}\end{array}$} & \multirow{2}{*}{ 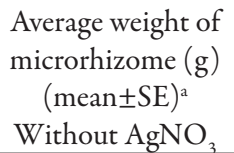 } & \multirow{2}{*}{ 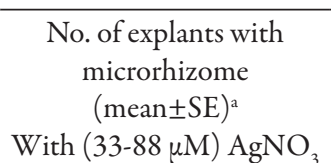 } & \multirow{2}{*}{ 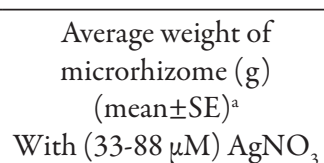 } \\
\hline NAA & BAP & Kn & & & & & & & \\
\hline 0 & 0 & 0 & 30 & 0.00 & 0.00 & 0.00 & 0.00 & 0.00 & 0.00 \\
\hline 1 & 1 & & 60 & $17.45 \pm 0.32 \mathrm{rs}$ & $0.78 \pm 0.03 \mathrm{~g}$ & $-\ldots-$ & ---- & $-\ldots-$ & ---- \\
\hline 1 & 1 & & 80 & $18.20 \pm 0.37 \mathrm{rs}$ & $1.10 \pm 0.03 \mathrm{~h}$ & $9.60 \pm 0.25$ xyzz & $0.36 \pm 0.01 \mathrm{plkz}$ & 0.00 & 0.00 \\
\hline 1 & 1 & & 100 & $6.50 \pm 0.32 \mathrm{yrl}$ & $0.67 \pm 0.008 \mathrm{e}$ & --- & --- & --- & -.-- \\
\hline 1 & 2 & & 60 & $21.90 \pm 0.39 \mathrm{ab}$ & $0.75 \pm 0.06 f$ & --- & --- & $-\cdots$ & --- \\
\hline 1 & 2 & & 80 & $24.80 \pm 0.26 y$ & $1.12 \pm 0.015 \mathrm{~h}$ & $15.8 \pm 0.35 \mathrm{xyrr}$ & $0.63 \pm 0.01 \mathrm{pptt}$ & 0.00 & 0.00 \\
\hline 1 & 2 & & 100 & $7.50 \pm 0.18 \mathrm{yrl}$ & $0.49 \pm 0.01 \mathrm{c}$ & -... & -..- & -... & -.-- \\
\hline 1 & 4 & & 60 & $25.45 \pm 0.26 y$ & $0.6 \pm 0.04 d$ &.--- & $-\ldots-$ & $-\ldots-$ & -..- \\
\hline 1 & 4 & & 80 & $36.25 \pm 0.27 \mathrm{pqrt}$ & $1.24 \pm 0.03 \mathrm{j}$ & $21.10 \pm 0.31$ xyyy & $0.84 \pm 0.11$ ppll & 0.00 & 0.00 \\
\hline 1 & 4 & & 100 & $6.40 \pm 0.13 \mathrm{yrl}$ & $0.72 \pm 0.02 \mathrm{e}$ & --- & -.-- & --- & --- \\
\hline 1 & 6 & & 60 & $22.25 \pm 0.39 \mathrm{ab}$ & $0.68 \pm 0.01 \mathrm{e}$ & $-\cdots$ & $-\cdots-$ & $-\ldots-$ & $-\cdots$ \\
\hline 1 & 6 & & 80 & $25.8 \pm 0.31 \mathrm{y}$ & $1.19 \pm 0.01 \mathrm{i}$ & $16.25 \pm 0.09$ xymm & $0.56 \pm 0.56$ pytz & 0.00 & 0.00 \\
\hline 1 & 6 & & 100 & $9.30 \pm 0.30 \mathrm{yrl}$ & $0.40 \pm 0.02 \mathrm{c}$ & -.-- & -.-- & $-\cdots$ & -..- \\
\hline 1 & & 1 & 60 & $17.30 \pm 0.37 \mathrm{pxz}$ & $0.80 \pm 0.02 \mathrm{~g}$ & $14.50 \pm 0.18$ xyll & $0.85 \pm 0.85$ ppll & 0.00 & 0.00 \\
\hline 1 & & 1 & 80 & $21.90 \pm 0.41 \mathrm{ab}$ & $1.03 \pm 0.004 \mathrm{~h}$ & --- & --- & $\ldots$ & -.- \\
\hline 1 & & 1 & 100 & $8.10 \pm 0.28 \mathrm{yrl}$ & $0.61 \pm 0.02 \mathrm{~d}$ & $-\cdots-$ & -..- & $-\cdots-$ & -.-- \\
\hline 1 & & 2 & 60 & $19.25 \pm 0.34 \mathrm{px}$ & $0.80 \pm 0.02 \mathrm{~g}$ & -... & -... & -... & $-\cdots$ \\
\hline 1 & & 2 & 80 & $22.30 \pm 0.46 \mathrm{ab}$ & $1.31 \pm 0.02 \mathrm{e}$ & $16.20 \pm 0.09$ xymm & $0.93 \pm 0.13 \mathrm{pqrt}$ & 0.00 & 0.00 \\
\hline 1 & & 2 & 100 & $6.80 \pm 0.23 \mathrm{yrl}$ & $0.51 \pm 0.02 \mathrm{c}$ & -..- & -..- & -..- & -..- \\
\hline 1 & & 4 & 60 & $18.45 \pm 0.26 \mathrm{rs}$ & $0.69 \pm 0.2 \mathrm{e}$ & -..- & $\ldots$ & $-\cdots-$ & $-\cdots$ \\
\hline 1 & & 4 & 80 & $22.05 \pm 0.48 \mathrm{abx}$ & $1.25 \pm 0.015 \mathrm{k}$ & $16.50 \pm 0.08 \mathrm{xymm}$ & $0.83 \pm 0.07$ ppll & 0.00 & 0.00 \\
\hline 1 & & 4 & 100 & $8.40 \pm 0.15 \mathrm{yrl}$ & $0.37 \pm 0.2 c$ & -.-- & -.-- & -.-- & ---- \\
\hline 1 & & 6 & 60 & $23.10 \pm 0.17 \mathrm{rx}$ & $0.77 \pm 0.2 \mathrm{~g}$ & $\ldots$ & $-\ldots-$ & $\ldots$ & $-\cdots$ \\
\hline 1 & & 6 & 80 & $23.85 \pm 0.15 \mathrm{pt}$ & $1.22 \pm 0.04 \mathrm{i}$ & $11.45 \pm 0.16 x y p p$ & $0.76 \pm .2 \mathrm{pstv}$ & 0.00 & 0.00 \\
\hline 1 & & 6 & 100 & $8.2 \pm 0.15 \mathrm{yrl}$ & $0.58 \pm 0.3 \mathrm{~d}$ & -.-- & --- & $\ldots$ & $\ldots$ \\
\hline 0.5 & & 2 & 60 & $17.25 \pm 0.25 \mathrm{pxz}$ & $0.68 \pm 0.2 \mathrm{e}$ & ---- & -.- & -..- & --.- \\
\hline 0.5 & & 2 & 80 & $19.1 \pm 0.16 \mathrm{px}$ & $1.34 \pm 0.06 \mathrm{~m}$ & $-\cdots$ & $-\cdots$ & $-\cdots$ & $-\cdots$ \\
\hline 0.5 & & 2 & 100 & $7.0 \pm 0.19 \mathrm{yrl}$ & $0.49 \pm 0.02 \mathrm{c}$ & --- & $-\cdots-$ & $-\ldots-$ & -.-- \\
\hline 0.5 & 4 & & 60 & $17.90 \pm 21 \mathrm{rs}$ & $0.71 \pm 0.02 \mathrm{e}$ & $-\cdots$ & $-\cdots-$ & $-\cdots-$ & ---- \\
\hline 0.5 & 4 & & 80 & $18.2 \pm 0.29 \mathrm{px}$ & $1.08 \pm 0.007 \mathrm{~h}$ & --- & -..- & -..- & -..- \\
\hline 0.5 & 4 & & 100 & $6.3 \pm 0.19 \mathrm{yrl}$ & $0.43 \pm 0.01 \mathrm{c}$ & $-\ldots-$ & $\ldots$ & $\ldots$ & $-\ldots$ \\
\hline
\end{tabular}

${ }^{2}$ Means followed by same letters are not significantly different at $p<0.05$, according to Tukey's comparison test 
74

nin-derived inhibition and stimulate the tuber formation (Lauzer et al., 1995).

Interaction of all plant growth hormones employed in the present investigation ( $\mathrm{Kn}, \mathrm{BAP}$ and NAA) with high sucrose level and $11 \mu \mathrm{M} \mathrm{AgNO}_{3}$ induced renewal bud formation along with microrhizome on the turmeric explants. The present results indicate that, in vitro microrhizome formation due to higher sucrose concentration may be due to presence of high carbon energy source in the form of sucrose. Since storage organ mostly store carbohydrates, high concentration of sucrose and BAP may have enhanced microrhizome production in Zingiberaceae (Nayak, 2000; Sharma and Singh, 1995). The tendency of the larger vessels lead to the production of high frequency microrhizome may be important to employ and can be another way of avoiding the damage caused by different diseases and will thus improve turmeric propagation with positive consequences in any micropropagation program.

\section{Effect of silver nitrate on in vitro microrbizome} production

The addition of $11 \mu \mathrm{M} \mathrm{AgNO}$ in the medium improved the regeneration frequency in all the culture tested (Tab. 4). The highest number of microrhizome production in vitro was seen in medium containing $11 \mu \mathrm{M} \mathrm{AgNO}$ $(36.25 \pm 0.27)$ and are much efficient than medium devoid of $\mathrm{AgNO}_{3}$ ( Tab. 4), which is in conformity with Citra et al. (2005). Many reports have shown the positive effect of $\mathrm{AgNO}_{3}$ on plant tissue culture viz. cucumber (Mohiuddin et al., 1997); apple (Ma et al., 1998); Chinese cabbage (Zhang et al., 1998); cassava (Zang et al., 2001); pearl millet and sorghum (Oldach et al., 2001); date palm (Al-Khayri and Al-Bahrany, 2004) and rapeseed (Akasaka-Kennedy, 2005). $\mathrm{AgNO}_{3}$ at the concentration of 11 $\mu \mathrm{M}$ was very beneficial to shoot regeneration along with the number of microrhizome production in $C$. longa var. Lakadong. The mode of action of $\mathrm{AgNO}_{3}$ in plant tissue culture is assumed to be associated with physiological effects of ethylene, silver ions acting as a competitive inhibitor of ethylene action rather than inhibiting ethylene synthesis. However, in during the present investigation, the observed effects of $\mathrm{AgNO}_{3}$ on microrhizome production may support the hypothesis that this compound acts as a direct inhibitor of the ethylene action, which in turn regulates the availability of ethylene in the culture vessel during specific stages of organ development.

In control experiment (Tab. 4), without $\mathrm{AgNO}_{3}(\mathrm{P} 2)$, in vitro derived plantlets showed low frequency microrhizome formation as compared with medium supplemented with $\mathrm{AgNO}_{3}(\mathrm{P} 1)$ at different concentration and combination of auxin ( $\left.1 \mathrm{mg} \mathrm{L}^{-1} \mathrm{NAA}\right)$ and cytokinins $(1,2,4,6 \mathrm{mg}$ $\mathrm{L}^{-1} \mathrm{BAP}$ and 1, 2, 4, $6 \mathrm{mg} \mathrm{L}^{-1} \mathrm{Kn}$ ) with $8 \%$ sucrose. Highest microrhizome were produced in medium supplemented with $1 \mathrm{mg} \mathrm{L}^{-1} \mathrm{NAA}$ and $4 \mathrm{mg} \mathrm{L}^{-1} \mathrm{BAP}(21.10 \pm 0.31)$ which was much lower as compared with medium supplemented with $\mathrm{AgNO}_{3}(36.25 \pm 0.27)$. However, this observation suggested that the poor regeneration response found in control experiment (without $\mathrm{AgNO}_{3}$ ) of $C$. longa may be associated with ethylene production by in vitro cultured cells or tissues.

Inhibitory effect of $\mathrm{AgNO}_{3}$ in higher conc. were studied by preparing the medium supplemented with $8 \%$ sucrose, $1 \mathrm{mg} \mathrm{L}^{-1} \mathrm{NAA}, 4 \mathrm{mg} \mathrm{L}^{-1} \mathrm{BAP}, 2 \mathrm{mg} \mathrm{L}^{-1} \mathrm{Kn}$ and 33-88 $\mu \mathrm{M} \mathrm{AgNO}_{3}$ in $250 \mathrm{ml}$ phytajar (Tab. 5).

Is been observed that high conc. of $\operatorname{AgNO}_{3}(33,44,66$, $88 \mu \mathrm{M})$ have inhibitory effect rather than stimulating effect in microrhizome formation which was contrast with the finding of Zhu et al. (1998), which shows increased positive response in $16 \mathrm{mg} \mathrm{L}^{-1} \mathrm{AgNO}_{3}$.

\section{Analysis of in vitro developed plantlets with and without AgNO3 treatment during acclimatization}

Micropropagation of many plants is achieved through the establishment of explants, their initial growth in vitro being followed by transplanting into ex vitro condition (shade house). Most often, used of rapid multiplication of many plant species are restricted by the often high frequency of plant lost or damage during field transfer. Transfer of plantlets, from tissue culture environment to the shade house cause tissue stress and is often associated with slow growth and significant plant losses. To overcome such chronic issue, acclimatization units have been developed with temperature, humidity, irradiance, $\mathrm{CO}_{2}$ conc. and air flow rate controlled by computer (Hayashi et al., 1988).

Tab. 5. Effects of higher conc. of $\mathrm{AgNO}_{3}$ in in vitro microrhizome production $(\mathrm{n}=20)$

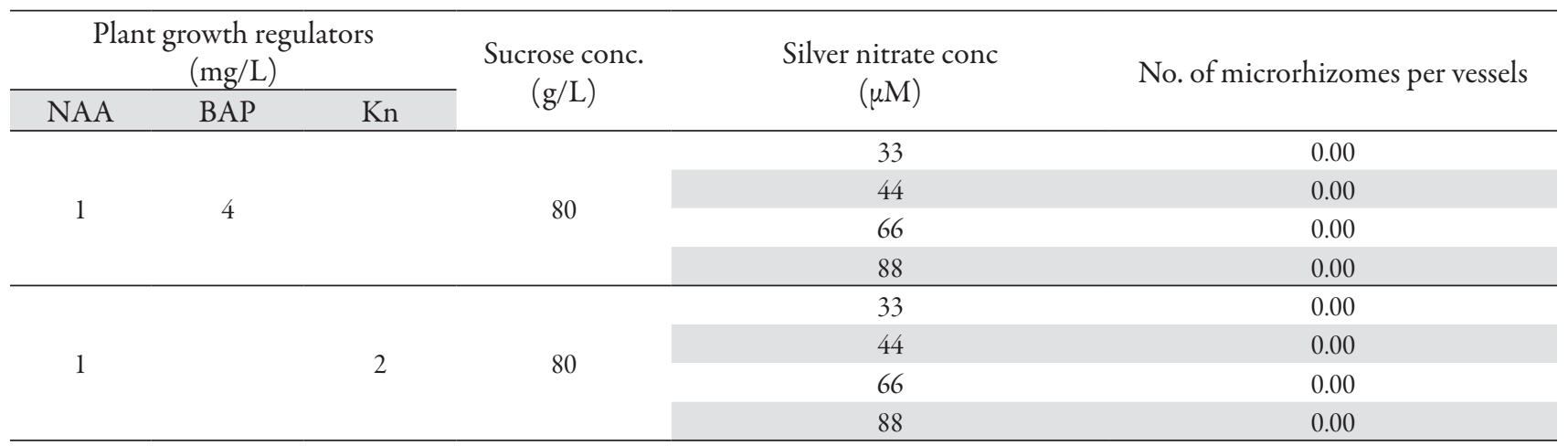

${ }^{a}$ Means followed by same letters are not significantly different at $p<0.05$, according to Tukey's comparison test 
During the present investigation, in vitro developed plantlets with microrhizome are monitored directly under shade house without primary hardening stage or any acclimatization units. P1 and P2 was transfer separately to sterilized soil and were maintained in shade house $(80 \%$ relative humidity and about $16 \mathrm{~h}$ photoperiod). Different parameter such as plant height, no. of leave, leaf length, no. of root, rhizome weight, and survival rate were recorded every after 2 weeks of initial establishment (Tab. 6). 9095\% (P1, Fig. 4) and 75-80\% (P2, Fig. 5) survival rates were documented during field establishment.

Among P1 and P2, P1 shows much higher plant height $(31.00 \pm 0.22 \mathrm{~cm})$ then P2 $(17.59 \pm 0.08 \mathrm{~cm})$ (Fig. 6).

The optimum growth rate of deflasked plantlets frequency does not occur until new leaf and root developed in ex vitro environment. No. of leave $(7.70 \pm 0.17)$ as well as no. of root $(15.75 \pm 0.18)$ were developed more in P1 as compared with $\mathrm{P} 2$, which shows leave and root multiplication of only $5.70 \pm 0.19$ and $8.30 \pm 0.10$ respectively. Since, rhizome is the key aspect in commercial exploitation of C. longa, larger minirhizome $(5.37 \pm 0.11 \mathrm{~g})$ were

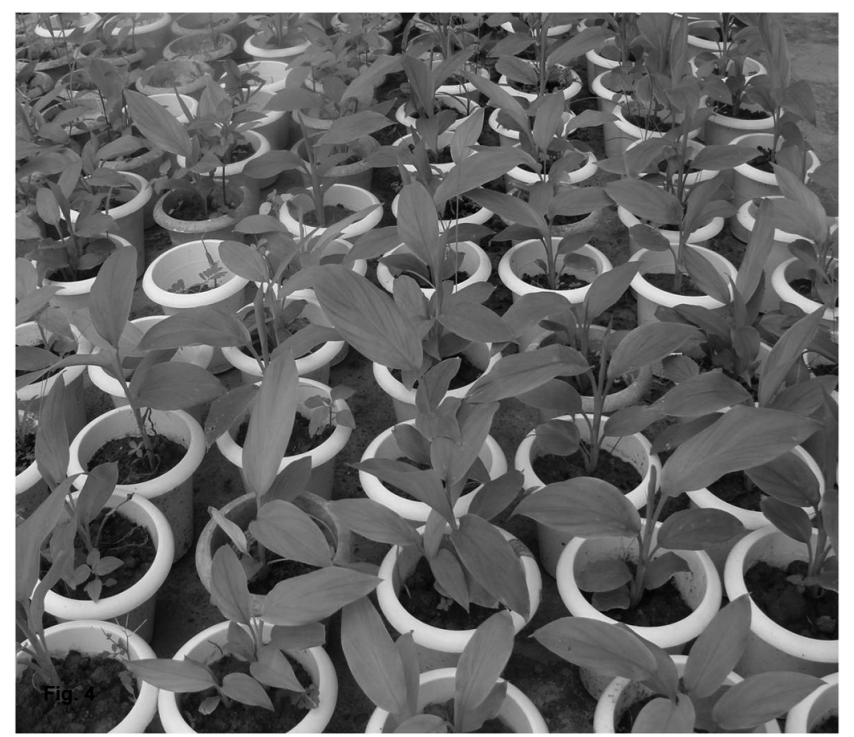

Fig. 4. Established plants with the presence of Silver nitrate in shade house

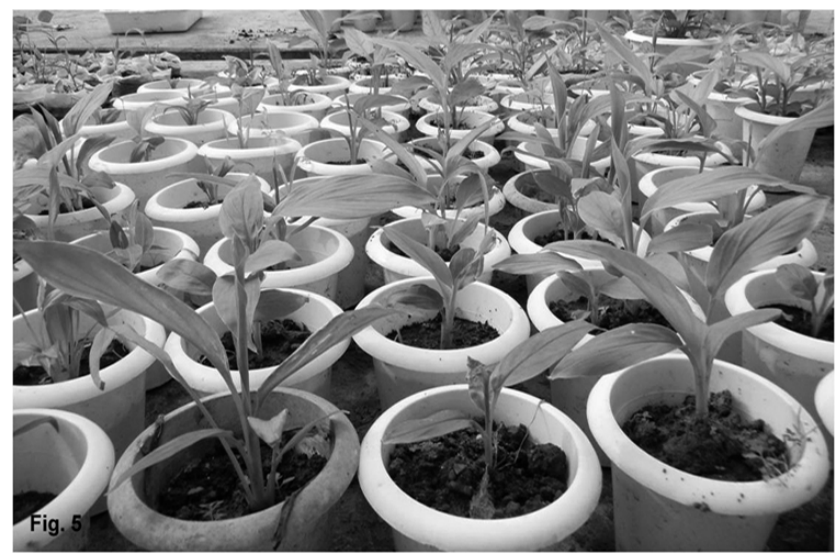

Fig. 5. Established plants without Silver nitrate in shade house achieved from P1 then P2 $(2.53 \pm 0.13 \mathrm{~g})$. However, from the overall observation P1 shows superior quality over P2 accordance to different parameter tested. This may be due to ethylene inhibitory effect of $\mathrm{AgNO}_{3}$, which in lower concentration cause delayed senescence resulting in improved growth of the shoots (Fuentes et al., 2000). The influence of exogenously applied of silver ions in the form of $\mathrm{AgNO}_{3}$ significantly regulates the ethylene activity in the plant systems. The major morphological effect of $\mathrm{AgNO}_{3}$ treatment was achieved during ex vitro conditions in turmeric via the above observation. The mode of action of $\mathrm{AgNO}_{3}$ in plant tissue culture assumed to be associated with the physiological effect of ethylene, silver ions acting as a competitive inhibitor of ethylene action rather than inhibiting ethylene synthesis per se. Ethylene production infact, increased in plant cultures treated with $\mathrm{AgNO}_{3}$ (Lee et al., 1997; Pua and Chi, 1993; Zhang et al., 1998). Even though, the mechanism of ethylene action on plant tissue culture has not been elucidated, from the present investigation, during field analysis (Tab. 6) higher transformation frequencies, more efficient and faster growth (P1) of $C$. longa may be due to the above hypothesis.

\section{Comparative leaf anatomy of in vitro and ex vitro derived leaf}

T.S of in vitro (Fig. 7 a) and ex vitro (Fig. 7 b) derived leaf of $C$. longa var. Lakadong indicate isobilateral types of leaf with single raw of abaxial and adaxial epidermis (Fig. 7).

The mesophyll is not differentiated but consists solely of spongy mesophyll tissue. Sunken stomata are observed which is kidney-shaped in surface view. A few cells in the lower epidermis are enlarged to form mother cells called bulliform cells. In both the section of in vitro (Fig. 7 a) and ex vitro (Fig. 7 b) derived leaf, vascular bundle surrounded by single layer of compactly arranged cells. Xylem

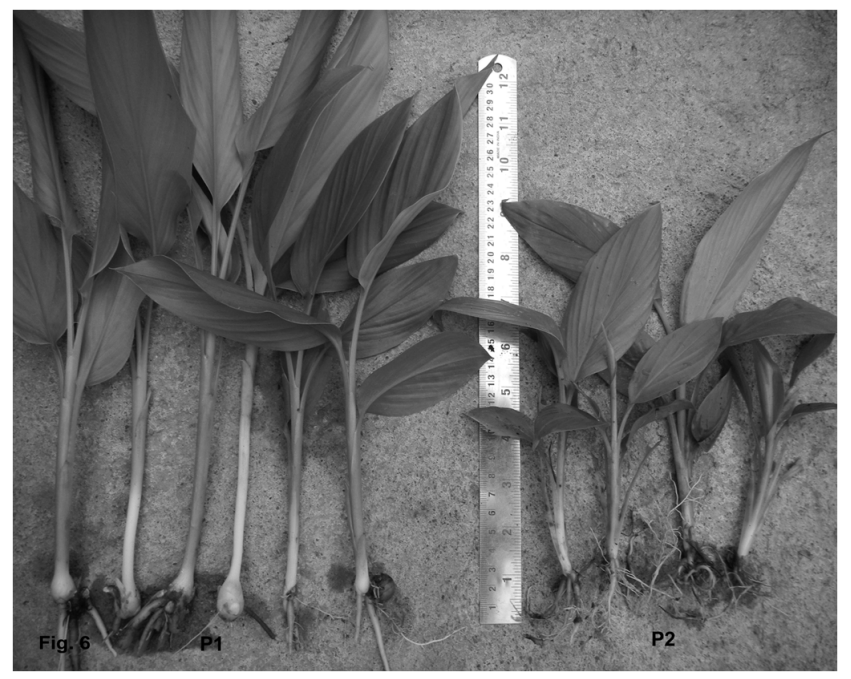

Fig. 6. Comparative morphology analysis of in vitro developed plantlets with and without $\mathrm{AgNO}_{3}$ treatment during acclimatization 
76

Tab. 6. Morphological analysis of in vitro plantlets treated with or without $\mathrm{AgNO}_{3}$ during ex vitro acclimatization after 60 days of initial establishment $(\mathrm{n}=20)$

\begin{tabular}{ccc}
\hline Parameter & $\begin{array}{c}\text { Plantlets } \\
\text { with AgNO } \\
\text { treatment }(\mathrm{P} 1)\end{array}$ & $\begin{array}{c}\text { Plantlets } \\
\text { with AgNO }\end{array}$ \\
treatment $(\mathrm{P} 2)$
\end{tabular}

${ }^{2}$ Means followed by same letters are not significantly different at $p<0.05$, according to Tukey's comparison test

was found towards upper and phloem towards lower epidermis. Oldest and the largest vascular bundle (ovb) were found in the centre and known as midrib vein. As the veins typically all parallel to each other in the blade, all appear in a cross sectional view in a cross section of the leaf. Two large stoma are present on both side of midrib vein called air space or air canals (ac). $3^{\text {rd }}$ to $6^{\text {th }}$ layer of upper mesophyll cells (uc) are larger and more regularly arranged than the central cells of the mesophyll. However, anatomical comparisons of in vitro and ex vitro derived leaf does not show any variability and the structures of cells of different tissues including the shunken stomata, mesophyll cells, large stoma, large vascular bundle, bulliform cells etc. were found to be similar in both the section studied.

\section{Anatomical study of in vitro derived microrbizome}

The cross-section of in vitro microrhizome showed the epidermis, the cortex and the vascular bundles comprising typical 'scattered' bundles of monocotyledons, distributed randomly in the fundamental tissue. The parenchyma cells contain a great quantity of starch grains. In the T.S

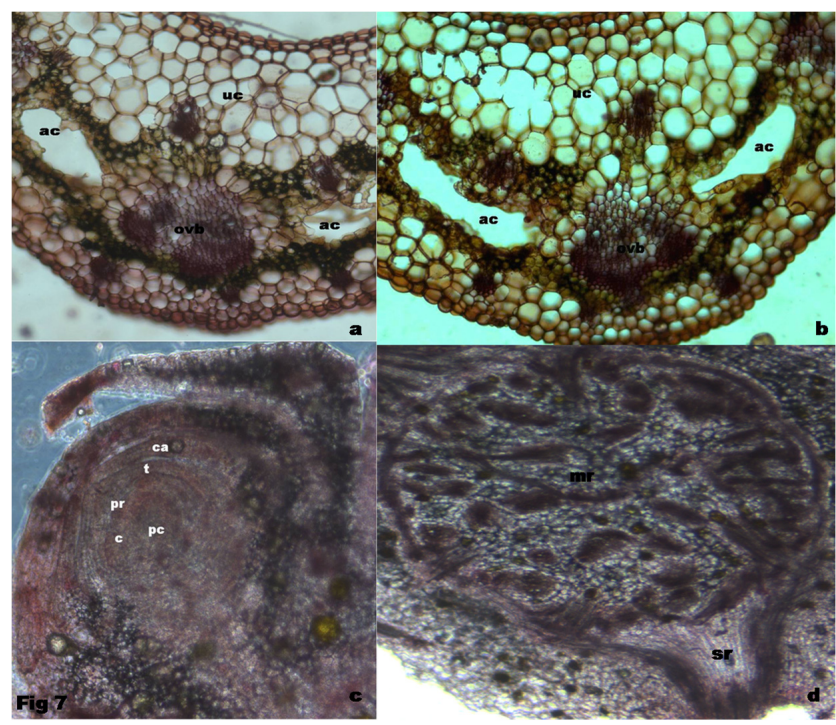

Fig. 7. a) T. S of In vitro derived leaf; b) T. S of ex vitro derived leaf; c) and d) T. S. of in vitro derived microrhizome the promeristematic region ( $\mathrm{pr}$ ) showed a tunica-corpus organization, with a layer of tunica $(t)$ and two or three layers of corpus (c) (Fig. 7 c). In the apical meristems, procambium strands (ps) were observed in the inner region, and also surrounding the vascular cylinder. The stem apex is protected by cataphylls (ca) (Fig. $7 \mathrm{~d}$ ).

In conclusion, the present study indicates a competent protocol for large scale production of microrhizome within a short period of time. Unnecessary expenditure for storage and transport of seed rhizomes for annual plantation can be avoided completely and ensured the availability of quality planting material throughout the year. It is imperative to produce disease free quality planting material in large scale simply by manipulating the in vitro requirement such as different growth vessels and plant growth regulators, sucrose concentration, and $\mathrm{AgNO}_{3}$. These studies provide a platform for large scale propagation of turmeric which is difficult to multiply by conventional methods, and a better strategy to conserve the germplasm.

\section{Acknowledgements}

Authors are grateful to the Department of Biotechnology (DBT), Government of India, New Delhi, India, for financial assistance, BT/PR7861/NDB/51/114/2006.

\section{References}

Akasaka Kennedy Y, Yoshida H, Takahata Y (2005). Efficient plant regeneration from leaf of rapeseed (Brassica napus L.): the influence of $\mathrm{AgNO}_{3}$ and genotype. Plant Cell Reports 24:649-654.

Al Khayri JM, Al Bahrany AM (2004). Genotype dependent in vitro response of date palm (Phoenix dactylifera L.) cultivars to silver nitrate. Scientia Horticulturae 99(2):153-162.

Anonymous (1984). Official methods of analysis. Association of official analytical chemists, $14^{\text {th }}$ edition, Washington, $153 \mathrm{p}$.

Ascough GD, Erwin JE, Van Staden J (2008). Reduced temperature, elevated sucrose, continuous light and gibberellic acid promote corm formation in Watsonia vanderspuyiae. Plant Cell Tissue Organ Cult 95:275-283.

Bais HP, George J, Ravishankar GA (1999). Influence of polyamines on growth of hairy root cultures of witl of chiocory (Chichorium intybus L cv 'Lucknow Local') and formation of coumarins. Journal of Plant Growth Regulation 18(1):33-37.

Bais HP, Sudha G, Suresh B, Ravishankar GA (2000 a). $\mathrm{AgNO}_{3}$ influences in vitro rootformation in Decalepis hamiltonit Wight, Arn. Current Science 79:894-898.

Bais HP, Sudha GS, Ravishankar GA (2000 b). Putrescine and $\mathrm{AgNO}_{3}$ influences shoot multiplication in vitro flowering and endogenous titres of polyamines in Chichorium intybus L cv 'Lucknow Local'. Journal Plant Growth Regulation 19(2):238-248.

Bais HP, Sudha GS, Ravishankar GA (2001 a). Influence of putrescine $\mathrm{AgNO} 3$ and polyamine inhibitors on the morpho- 
genetic response in untransformed and transformed tissues of Chichorium intybus and their regenerants. Plant Cell Reportsvol 20(6):547-555.

Bais HP, Venkatesh RT, Chandrashekar A, Ravishankar GA (2001 c). Agrobacterium rhizogenes mediated transformation of witl of chiocory in vitro shoot regeneration and induction of flowering. Curr Sci80:83-87.

Bais HP, Sudha GS, Ravishankar GA (2001 b). Putrescine influences growth and production of coumarins in transformed and untransformed root cultures of witl of chicory (Chichorium intybus L cv 'Lucknow Local'). Acta Physiologia Plantarum 23:319-327.

Beyer EM (1976 a). A potent inhibitor of ethylene action in plants. Plant Physiology 58(3):268-271.

Beyer EM (1976 b). Silver ion: a potent anti-ethylene agent in cucumber and tomato. Hort Scienceb 11(3):175-196.

Bhagyalakshmi G, Singh NS (1988). Meristem culture and micropropagation of a variety of ginger (Zingiber officinale Rosc.) with a high yield of oleoresin. J Hort Sci 63:321327.

Borthakur M, Bordoloi DN (1992). Micropagation of Curcuma amada Roxb. J. Spice and Aromatic Crops 1:154-156.

Borthakur M, Hazarika J, Singh RS (1999). A protocol for micropropagation of Alpinia galanga. Plant Cell, Tissue and Organ Culture 55:231-233.

Chang BKW, Chiley RA (1993). Clonal propagation of pink ginger in vitro. Hort Science 28:1203.

Chattopadhay I, Biswas K, Bandyopadyay U, Banerjee K (2004). Turmeric and curcumin: Biological actions and medicinal Applications. Current Science 87:44-53.

Chi GL, Pua EC (1989). Ethylene inhibitors enhanced de novo shoot regeneration from cotyledons of Brassica campastris spp in vitro. Plant Science 64:243-250.

Chithra M, Martin KP, Sunandakumari C, Madhusoodanan PV (2005). Protocol for rapid propagation and to overcome delayed rhizome formation in field established in vitro derived plantlets of Kaempferia galanga L. Sci Hort 104:113-120.

Davies PJ (1987). The plant hormones: their nature, occurrence, and functions. In: Davies PJ (Ed.). Plant Hormones and Their role in Plant Growth and Development. Ch. Al. Boston: Martinus Nijhoff.

Debergh PC, Zimmerman RH (1991). Micropropagation. Technology and application. Kluwer Academic publishers. Dordrecht, TheNetherlands 7:1-93.

Dohroo NP (1989). Seed transmission of pre-emergence rot and yellows in ginger. Plant Dis Res 4:73-74.

Duncan DR, Williams ME, Zehr B, Widholm JM (1985). The production of callus capable of plant regeneration from immature embryos of numerous Zea mays genotypes. Planta 165(3):322-332.

Fuentes SRL, Calheiros MBP, Manettifilho J, Vieira LGE (2000). The effects of silver nitrate and different carbohydrate sources on somatic embryogenesis in Coffea canephora. Plant Cell Tissue Organ Culture 60(1):5-13.
Garner N, Blake J (1989).The induction of potato microtubers in vitro on media free growth regulatory substances. Ann Bot 63:666-674.

George EF (1993). Plant Propagation by Tissue Culture. Part I. The Technology, Exegetics Ltd., Edington, Wilts, UK.

Gerrits MM, De Klerk GJ (1992). Drymatter partitioning between bulbs and leaf in plantlets of Lilium speciosum regenerated in vitro. Acta Bot Neerl 41(4):461-468.

Giridhar P, Indu EP, Vijaya Ramu D, Ravishankar GA (2003). Effect of silver nitrate on in vitro shoot growth of Coffee. Tropical Science 43(3):144-146.

Gopal J, Chamail A, Sarkar D (2001). In vitro production of microtubers for conservation of potato germplasm: effect of genotype, abscisic acid, and sucrose. In vitro cell Dev Biolplant 40:185-190.

Hayashi M, Nakayama M, Kozai T (1988). An application of the acclimatization unit for growth of carnation explants, and for rooting and acclimatization of the plantlets. Acta Hort 230:189-194.

Hosoki T, Sagawa Y (1977). Clonal propagation of ginger (Zingiber officinale Rosc.) through tissue culture. Hort Science 12:451-452.

Huang C, Chen C (2005). Physical properties of culture vessels for plant tissue culture. Biosystems Eng 91:501-511.

Inden H, Asahira T, Hirano A (1988). Micropropagation of ginger. Acta Hortic 230:177-184.

Kacar YA, Bicen B, Varol I, Mendi YY, Serce S, Cetiner S (2010). Gelling agents and culture vessels affect in vitro multiplication of banana plantlets. Genet Mol Res 99(1):416-424.

Kastner U, Klahr A, Keller ERJ, Kahane R (2001). Formation of onion bulblets in vitro and viability during medium-term storage. Plant Cell Rep 20:137-142.

Keller ERJ (1993). Sucrose, cytokinin, and ethylene influence formation of in vitro bulblets in onion and leek. Genet Resour Crop Evol 40:113-120.

Lauzer D, Laublih G, Vincent G, Cappadoria M (1995). In vitro propagation and cytology of wild yams, Dioscorea abyssinica Hoch. and Dioscorea mangenotica Miege. Plant Cell Tisues Organ Cult 28:215-223.

Lee T, Huang MEE, Pua EC (1997). High frequency shoot regeneration from leaf disc explants of garland chrysanthemum (Chrysanthemum coronarium L.) in vitro. Plant Sci 126:219-226.

Ma JH, Yao JL, Cohen D, Morris B (1998). Ethylene inhibitors enhance in vitro root formation from apple shoot cultures. Plant Cell Reports 17:211-214.

Lopez-Lazaro M (2008). Anticancer and carcinogenic properties of curcumin: Considerations for its clinical development as a cancer chemopreventive and chemotherapeutic agent. Mol Nutr Food Res 52:S103-S127.

Misra P, Datta SK, Johri JK, Singh HB, Srivastava A (2004). An improved method for in vitro large scale propagation of Piper betel L. J Plant Biochemistry and Biotechnology 13:161-164. 
78

Mohiuddin AKM, Chowdhury MKU, Abdulla ZC, Napis S (1997). Influence of silver nitrate (Ethylene inhibitor) on Cucumber shoot regeneration. Plant Cell, Tissue and Organ Culture 51(1):75-78.

Murashige T, Skoog F (1962). A revised medium for rapid growth and bioassays with tobacco tissue cultures. Physiol Plant 15:473-497.

Nasirujjaman KM, Uddin S, S Zaman, MA Reza (2005). Micropropagation of Turmeric (Curcuma longa Linn.) through in vitro Rhizome Bud Culture. Journal of Biological Sciences 5(4):490-492.

Nayak S (2000). In vitro multiplication and microrhizome induction in Curcuma aromatica Salisb. Plant Growth Regulation 32:41-47.

Oldach K, Morgenstern A, Rother S, Girgi M, O Kennedy M, Lorz $H$ (2001). Efficient in vitro plant regeneration from immature zygotic embryos of Pearl millet [Pennisettum glaucum (L) R Br] and Sorgum bicolor (L) Moench. Plant Cell Reports 20(5):416-421.

Omokolo ND, Boudjeko T, Tsafack Takadong JJ (2003). In vitro tuberization of Xanthosoma sagittifolium L. Schott: effect of phytohormones, sucrose, nitrogen and photoperiod. Sci Hort 98:337-345.

Ovono PO, Kevers C, Dommes J (2009). Effects of reducing sugar concentration on in vitro tuber formation and sprouting in yam (Dioscorea cayenensis - D. rotundata complex). Plant cell tissue organ cult 99:55-59.

Panda MK, Mohanty S, Subudhi E, Acharya L, Nayak S (2007). Assessment of genetic stability of micropropagated plants of Curcuma longa by cytophotometry and RAPD analyses. International Journal of Integrative Biology 1(3):189-195.

Pieris N (1982). Ginger. Ceylon Institute of Scientific and Industrial Research, Colombo 07:1-17.

Prathanturarug S, Soonthornchareonnon N, Chuakal W, Phaidee Y, Saralamp P (2003). High-frequency shoot multiplication in Curcuma longa L. using thidiazuron. Plant Cell Rep 21:1054-1059.

Praveen K (2005). Variability in Somaclones of Turmeric (Curcuma longa L.) Ph.D Thesis. Calicut University, Kerala.

Pua EC, Chi GL (1993). De novo shoot morphogenesis andplant growth of mustard (Brassica juncea) in vitro in relation to ethylene. Physiol Plant 88:467-474.

Purnhauser L, Medgysey P, Czako M, Dix JP, Marton L (1987). Stimulation of shoot regeneration in Triticum aestivum and Nicotiana plumbaginifolia Viv tissue cultures using the ethylene inhibitor silver nitrate. Plant Cell Reports 6(1):1-4.

Raghu RV (1997). Micropropagation of turmeric (Curcuma longa L.) by in vitro microrhizomes. In: Edison S, Ramana KV, Saskumar B, Nirmal BK, Santhosh JE (Eds.). Biotechnology of species, medicinal and aromatic crops. Indian Society for spices, Calicut, Kerala, India.

Rahman MM, Amin MN, Jahan HS, Ahmed R (2004). In vitro regeneration of plantlets of Curcuma longa L.: a valuable spice plant of Bangladesh. Asian J Plant Sci 3:306-309.

Rolland F, Baena Gonzalez E, Sheen J (2006). Sugar sensing and signaling in plants: Conserved and novel mechanisms. Annu
Rev Plant Boil 57:675-709.

Roy S, Raychaudhuri S (2004). In vitro regeneration and estimation of curcumin content in four species of Curcuma. Plant Biotechnol 21:299-302.

Sanghamitra N, Nayak S (2000). In vitro microrhizome production in four cultivars of turmeric (Curcuma longa L.) as regulated different factors. In: Spices and aromatic plants - challenges and opportunities in the new century. Indian Society for Species, Calicut, Kerala, India.

Sato M, Kuroyanagi M, Ueno A, Shimomura K, Satake M (1987). Plant tissue culture of Zingiberaceae(II) in vitro propagation of turmeric (Curcuma longa Linn.). Plant Tiss Cult Lett 4:86-88.

Satyavati GV, Raina MK, Sharma M (Eds.) (1976). Medicinal Plants of India, Vol. 1 (312-317). Indian Council of Medical Research, New Delhi.

Sharma TR, Singh BM (1995). In vitro microrhizome production in Zingiber officinale Rosc. Plant Cell Rep 15:274-7.

Shirgurkar MV, John CK, Nadgauda RS (2001). Factors affecting in vitro micro-rhizome production in turmeric. Plant Cell, Tissue and Organ Cult 64(1):5-11.

Shukla Y, Singh M (2007). Cancer Preventive Properties of Ginger: A Brief Review. Food Chem Toxicol 45(5):683-690.

Smart J, Simmonds NW (1992). Evolution of Crop Plants. Longman, Edinburgh, 333 p.

Smeekens S (2000). Sugar-induced signal transduction in plants. Annu. Rev. Plant physiol. Plant Mol Biol 51:49-81.

Songstad DD, Duncan DR, Widholm JM (1988). Effect of 1-aminocycopropane-1-carboxilic acid silver nitrate and norbornadiene on plant regeneration from maize callus cultures. Plant Cell Reports 7(4):262-265.

Sunitibala H, Damayanti M, Sharma GJ (2001). In vitro propagation and rhizome formation in Curcuma longa Linn. Cytobios 105(409):71-82.

Takayama S, Misawa M (1980). Differentiation in Lilium bulbscales grown in vitro. Effects of activated charcoal, physiological age of bulbs and sucrose concentration on differentiation and scale leaf formation in vitro. Physiol Plant 48:121-125.

Vidya SM, Krishna V, Manjunatha BK, Shankarmurthy K (2005). Micropropagation of Entada pursaetha DC- An endangered medicinal plant of Western Ghats. Indian J Biotechnology 4:561-564.

Vreugdenhil D, Boogaard Y, Visser RGF, Bruijn SM (1998). Comparison of tuber and shoot formation from in vitro cultured potato plants. Plant Cell Tiss Org Cult 53:97-204.

Zang P, Phansiri S, Kaerlas JP (2001). Improvement of cassava shoot organogenesis by the use of $\mathrm{AgNO}_{3}$ in vitro. Plant Cell Tissue Organ Culture 67(1):47-54.

Zhang FL, Takahata Y, Xu JB (1998). Medium and genotype factors influencing shoot regeneration from cotyledonary explants of Chinese cabbage (Brassica campestris L. ssp. pekinensis). Plant Cell Reports 17:780-786.

Zhu J, Huang YW, Liang CY (1998). Improvement of plant regeneration from cyclic secondary somatic embryos in cassava (Manihot esculenta Crantz). J Trop Sub trop Bot 6(2):144151. 